\title{
EVALUATION OF EFFICACY OF PROVIDING HYGIENE EDUCATION TO SCHOOLCHILDREN AND STUDENTS IN THE PROCESS OF DEVELOPMENT OF THE SAFE ELECTRONIC DEVICE USE SKILLS
}

Milushkina OYu, Markelova SV $\bowtie$, Skoblina NA, Moiseev AB, Alsabunchi AA, Tatarinchik AA, Savchuk PO, levleva OV

Pirogov Russian National Research Medical University, Moscow, Russia

\begin{abstract}
The negative impact of the digital environment on the health of young people necessitates the search for new methods of hygienic education. This study aimed to test and assess the hygienic qualities of the practice designed to give students and schoolchildren the skills allowing safe use of electronic devices. The study involved 256 students, 200 senior schoolchildren, 400 teachers and 251 parent. The hygienic education practice relied on the healthy lifestyle materials published in scientific literature, as well as materials posted on the Internet resources of medical organizations professionally engaged in the area considered, as well as their groups in the social networks Odnoklassniki, VKontakte, Facebook, Instagram, etc. We observed physical development of the schoolchildren and students dynamically and polled schoolchildren, students, teachers, and parents. For statistical processing of the results, we used methods of descriptive statistics, Student's t-test, correlation, discriminant and cluster analysis, and calculated risks. As the most popular source of information about health maintenance, Internet scored as follows: among schoolchildren $-79.0 \%$, students $-88.6 \%$, parents $-64.9 \%$, teachers $-50.4 \%$. The tested hygienic education practice allowed for a reduction of the number of schoolchildren and students who did not have the skills to safely use electronic devices to 20 and $25 \%$, respectively. The practice also taught the participants to reduce their daily smartphone use time, engage in physical activity more often, which ultimately increased the share of children whose physical development was normal $(p \leq 0.01)$, and helped to increase the duration of night sleep. The tested methods of education are not costly; they can be replicated in other regions and organizations.
\end{abstract}

Keywords: schoolchildren, students, electronic devices, rules of use, hygiene education, assessment of the effectiveness

Author contribution: OYu Milushkina, NA Skoblina — research planning and management, material processing, authoring; AB Moiseev — authoring: AA Alsabunchi, SV Markelova, AA Tatarinchik — literature data analysis, material collection and processing, authoring; PO Savchuk, OV levleva — material collection.

Compliance with ethical standards: the study was approved by the Ethics Committee of the Pirogov Russian National Research Medical University (Minutes \#159 of November 21, 2016), conducted in compliance with the ethical standards provided by the Declaration of Helsinki and the European Community Directives (8/609 EU). Each participant signed a voluntary informed consent form. The participating adults (parents and teachers) were polled voluntary with the help of an online service.

$\triangle$ Correspondence should be addressed: Svetlana V. Markelova Ostrovityanova, 1, Moscow, 117997; markelova_sv@rsmu.ru

Received: 06.11.2020 Accepted: 17.12.2020 Published online: 29.12.2020

DOI: 10.24075/brsmu.2020.086

\section{ОЦЕНКА ЭФФЕКТИВНОСТИ ГИГИЕНИЧЕСКОГО ВОСПИТАНИЯ ШКОЛЬНИКОВ И СТУДЕНТОВ ПО ФОРМИРОВАНИЮ НАВЫКОВ БЕЗОПАСНОГО ИСПОЛЬЗОВАНИЯ ЭЛЕКТРОННЫХ УСТРОЙСТВ}

О. Ю. Милушкина, С.В.Маркелова $\bowtie$, Н. А. Скоблина, А. Б. Моисеев, А. А. Аль-Сабунчи, А. А. Татаринчик, П. О. Савчук, О.В.Иевлева

Российский национальный исследовательский медицинский университет имени Н. И. Пирогова, Москва, Россия

Негативное влияние цифровой среды на здоровье молодежи стимулирует поиск новых приемов гигиенического воспитания. Целью работы были апробация и гигиеническая оценка эфффективности практики формирования здорового образа жизни у студентов и школьников в части формирования навыков безопасного использования электронных устройств. В исследовании приняли участие 256 студентов, 200 учащихся старших классов, 400 преподавателей и 251 родитель. Гигиеническое воспитание осуществляли с использованием опубликованных в научной литературе материалов по здоровому образу жизни, а также материалов, размещенных на Интернет-ресурсах медицинских организаций, профессионально работающих в этой области и их группах в социальных сетях “Одноклассники», «ВКонтакте», «Facebook», «Инстаграм» и др. Было организовано динамическое наблюдение за физическим развитием школьников и студентов, а также анкетирование школьников, студентов, преподавателей, родителей. Для статистической обработки результатов использовали методы описательной статистики, $t$-критерий Стьюдента, корреляционный, дискриминантный и кластерный анализы, проводили расчет рисков. Наиболее популярным источником информации о сохранении здоровья респонденты отметили Интернет: среди школьников - 79,0\%, студентов - 88,6\%, родителей - 64,9\%, преподавателей - 50,4\%. Апробированная практика гигиенического воспитания позволила снизить число школьников и студентов, не имевших навыков безопасного использования электронных устройств до 20 и $25 \%$ соответственно; сократить продолжительность использования смартфона в течение дня; увеличить двигательную активность, а также долю детей с нормальным физическим развитием ( $p \leq 0,01)$; способствовала увеличению продолжительности ночного сна. Апробированные способы воспитания финансово не затратны и могут быть тиражированы в других регионах и организациях.

Ключевые слова: школьники, студенты, электронные устройства, правила использования, гигиеническое воспитание, оценка эфффективности

Вклад авторов: О. Ю. Милушкина, Н. А. Скоблина - планирование и научное руководство, обработка материала, написание статьи; А. Б. Моисеев написание статьи; А. А. Аль-Сабунчи, С. В. Маркелова, А. А. Татаринчик - анализ литературных данных, сбор и обработка материала, написание статьи; П. О. Савчук, О. В. Иевлева - сбор материала.

Соблюдение этических стандартов: исследование одобрено этическим комитетом РНИМУ им. Н. И. Пирогова (протокол № 159 от 21 ноября 2016 г.), проведено с соблюдением этических норм, представленных в Хельсинкской декларации и Директивах Европейского сообщества (8/609ЕС). Добровольное информированное согласие было получено для каждого участника программы. Опрос взрослого населения (родители и педагоги) проводился на добровольной основе с использованием онлайн-сервиса.

$凶$ Для корреспонденции: Светлана Валерьевна Маркелова ул. Островитянова, д. 1, г. Москва, 117997; markelova_sv@rsmu.ru

Статья получена: 06.11.2020 Статья принята к печати: 17.12.2020 Опубликована онлайн: 29.12.2020

DOI: $10.24075 /$ vrgmu.2020.086 
The target of the Healthy Lifestyle Popularization (Public Health Improvement) Priority Project is to raise the share of the Russian population living a healthy lifestyle to $60 \%$ by 2025 [1]. Project execution includes a large-scale information campaign in the media, on various Internet resources, in social networks. The campaign will focus on maintaining health. The project aims to invite healthy lifestyle $(\mathrm{HL})$ experts to collect, test and replicate the health maintenance best practices relevant for various groups of population.

Popularization of $\mathrm{HL}$ among children, adolescents and youth has always been regarded by specialists as a complex, systemic, multi-level process, covering all spheres of life of the younger generation [2-5].

All aspects of life are digitalized nowadays; this is a global trend. Digital environment affects significantly the learning process of children, adolescents and youth, their leisure time, socialization, health status and lifestyle [6-10].

Against the background of digitalization, children, adolescents and the youth have switched to the new main source of information on health preservation, the internet, and they rely on their parents, teachers and medical workers to a lesser extent in this regard [11].

Innovative methods of $\mathrm{HL}$ promotion become more important. Such include flash mobs, quests covered on social media, economic incentives and the like. They are more attractive to the young people compared to the traditional methods that were used several decades ago [12-14].

However, with the digitalization as it is currently, there are practically no research reports assessing effectiveness of the internet as the hygienic education enabler for the younger generation. The Yamal Center for Public Health and Medical Prevention can be taken as an example of the internet resource containing relevant information on the healthy lifestyle. Employees of the Center run an active information and communication campaign on various internet resources and social networks: they post materials on prevention of diseases and regularly hold various creative contests promoting healthy lifestyle. Similar work promoting prevention, including prevention of non-infectious diseases, is done by the specialists of the National Medical Research Center of Therapy and Preventive Medicine and the Center for Hygienic Education of the Population under Rospotrebnadzor.

The share of people living the healthy lifestyle and observing the rules of safe use of electronic devices (ED) is low [15-16]. This fact indicates that the existing preventive measures are insufficient, and there is a need to further research and intensify education efforts aimed at giving the younger generation hygiene skills, including those allowing them to use ED safely.

This study aimed to test and assess the effectiveness of the hygiene education of students and schoolchildren relying on the information available online, including education granting skills needed to use electronic devices safely.

\section{METHODS}

In the context of this study, $2^{\text {nd }}$ and $3^{\text {rd }}$ year medical students received hygiene education over the course of two years. The students were studying hygiene as part of the Federal State Educational Higher Education Standard. Another track of the study had Department of Hygiene employees and postgraduate students teaching ED safe use skills for study and leisure at Dolgoprudnenskaya Grammar School (Moscow region). The hygiene skills were taught to schoolchildren, their parents and teachers.

The study inclusion criteria were: voluntarily signed informed consent form; age of schoolchildren, students; correct completion of the questionnaire. The participating adults (parents and teachers) were polled voluntary with the help of an online service'.

Standard methods and tools enabled physical development dynamic control through the study [17].

The experimental group consisted of 128 medical students (mean age 20 years) and 100 schoolchildren (mean age 16 years); the participants attended Dolgoprudnenskaya Grammar School. The control group consisted of 128 medical students and 100 senior schoolchildren attending other schools at Dolgoprudny; they were not receiving hygiene education. The study also involved 251 parents and 400 teachers/ professors working at primary, secondary and higher education organizations.

We used all educational methods (verbal, printed, visual, mixed) and such means as conversation, discussion, lecture, memos, leaflets, posters, video materials, telecommunications etc. In particular, teaching schoolchildren and students hygiene, we employed materials published to the official websites and social network pages of the Yamal Center for Public Health and Medical Prevention, National Medical Research Center of Therapy and Preventive Medicine and the Center for Hygienic Education of the Population under Rospotrebnadzor, as well as videos posted to the YouTube channel.

Factoring in the high interest the youth, their parents and teachers have in social media and websites, and considering how deeply engaged they are with the online resources, we recommended them to seek $\mathrm{HL}$ information online, from the specialists available for consultations in the Odnoklassniki, VKontakte, Facebook, Instagram, Telegram social networks, as well on the websites of specialized medical organizations.

In addition, the official website of the Dolgoprudny Grammar School offered $\mathrm{HL}$ information with practical recommendations for teachers and parents.

We tested how some HL apps by various developers work in the context of provision of hygiene education. Such apps were installed by schoolchildren and students on their personal smartphones and allowed counting/monitoring body mass index, screen time, steps, nighttime sleep.

The program of the hygiene education measures relied on the use of the following: materials covering prevention of risks associated with the technical and audiovisual properties of ED (electromagnetic radiation, air ionization, screen diagonal, screen brightness level etc.), room microclimate parameters and illumination level; workplace ergonomics, work-rest balance information; information on prevention and healthimproving measures.

To assess the effectiveness of HL skills development in students and schoolchildren, we developed special questionnaires in Google Forms, which were made available to the participants [18]. The questionnaires contained questions designed to learn the peculiarities of ED use by schoolchildren and students, their level of awareness of the risks associated with uncontrolled use of ED, shape of their safe ED use skills, and subjective assessment of the respondents' health status [18].

The statistical processing of the data was enabled by Statistica 13.0 (StatSoft Inc.; USA). In our work, we used the methods of descriptive statistics, Student's t-test, correlation, discriminant and cluster analysis, risks calculation. The differences were considered significant at $p=0.05$

\section{RESULTS}

We employed both the traditional and innovative teaching methods and means in providing hygiene education to 
Table. Time schoolchildren spent using smartphones during the day and their body fat mass depending on the effectiveness of mastering the hygiene education program

\begin{tabular}{|c|c|c|c|c|c|}
\hline \multirow{2}{*}{ Indicator } & \multicolumn{2}{|c|}{$\begin{array}{l}\text { Group of schoolchildren that responded positively } \\
\text { to the hygiene education program }\end{array}$} & \multicolumn{2}{|c|}{$\begin{array}{l}\text { Group of schoolchildren that did not receive hygiene } \\
\text { education or for whom it was ineffective }\end{array}$} & \multirow[t]{2}{*}{$p$} \\
\hline & $\mathrm{Me}$ & {$\left[Q_{25} ; Q_{75}\right]$} & $\mathrm{Me}$ & {$\left[Q_{25} ; Q_{75}\right]$} & \\
\hline $\begin{array}{l}\text { Time spent using a smartphone } \\
\text { a day, minutes }\end{array}$ & 180 & {$[90 ; 300]$} & 720 & [480; 900] & $<0.001$ \\
\hline Body fat, kg & 12 & {$[9 ; 17]$} & 14 & {$[11 ;-23]$} & $<0.001$ \\
\hline
\end{tabular}

schoolchildren and students. The traditional methods and means were conversations, discussions using visual materials, leaflets and posters; the innovative set included business games, web quests, topical discussions with specialists online (on social media), information blogs, $\mathrm{HL}$ apps. The program was based both on the official materials and on the previously published information on the ED safe use rules that the authors developed in the context of their previous research efforts.

The questionnaires allowed identifying the time slot when using an ED is safe, i.e. when schoolchildren and students report no complaints about their health. We registered significant differences $(p \leq 0.05)$ when comparing time spent using an ED by schoolchildren and students that complained and that did not complain about the state of their health. The complaining schoolchildren and students spent considerable more time using ED (given as Me $\left[Q_{1} ; Q_{3}\right]$ ) in minutes - $(660$ [420; 960]), than the schoolchildren/students reporting no complaints - (480 [360; 750]). To determine the likelihood of complaints associated with ED use, as well as to find the maximum allowable duration of such use that would not entail health complaints, we carried out discriminant analysis that yielded the following theoretical model:

$$
Y_{c}=-1.655+0.02 \times X_{\text {time }}
$$

where $Y_{c}$ is the discriminant function characterizing the likelihood of complaints; $X_{\text {time }}$ - time spent with an ED.

The constant of discrimination that divided the participants into two groups was determined as the value of the function equidistant from the centroids. In the no-complaints group it was - 0.216, and in the complaints group it equaled 0.080 . The sensitivity of the model reached $73.3 \%$, its specificity $62.6 \%$.

According to this model, schoolchildren and students may spend 78 minutes with an ED without developing health conditions entailing complaints afterwards. This figure formed the background for the hygiene education program developed. Based thereon, we established the allowed ED use time, workrest balance, breaks involving eye and body exercises.
The data obtained indicate there is a relationship between physical activity and the average time spent with a mobile ED daily, with the correlation ratio between the number of steps per day and the screen time at -0.36 . Based on these findings, we recommended replacing a portion of screen time with physical activity, decreasing the former and increasing the latter. The suggested educational effectiveness assessment criteria are the counted minutes of screen time and steps made.

The participants trust internet as the source of information, including health maintenance and $\mathrm{HL}$ advice. The aggregated levels of trust reported by them are as follows: students 88.6\%; senior schoolchildren - 79.0\%; parents - 64.9\%; teachers - 50.4\%. Considering this fact, we integrated materials published to the websites of specialized medical organizations and their social network pages, as well as online communication with specialists, into the hygiene education program.

Parents of schoolchildren and teachers who had completed the adapted training course and also seek information on the websites of specialized medical organizations participated in provision of hygiene education to the children.

The work in the context of this study allowed compiling a group of schoolchildren and students that responded well to the hygiene education.

The $H \mathrm{~L}$ apps schoolchildren used on their personal smartphones enabled them to monitor their body mass index, steps taken, screen time, and nighttime sleep duration. Students participating in the hygiene education program had the number of steps taken increased significantly compared to their peers not included in the study ( $p \leq 0.01$ ), the figures being $13.068 \pm 70$ vs $9033 \pm 90$ steps for boys and $8555 \pm 50$ vs $7807 \pm 70$ steps for girls, respectively.

According to the app registering nighttime sleep, schoolchildren participating in the study saw the duration of their sleep growing to 8 hours (482 \pm 42 minutes), which is close to hygienically justified recommendations, while schoolchildren not involved in the program did not exhibit such a trend. On average, the participating schoolchildren decreased their ED use time to 3.8 hours ( $230 \pm 30$ minutes) per a school day.

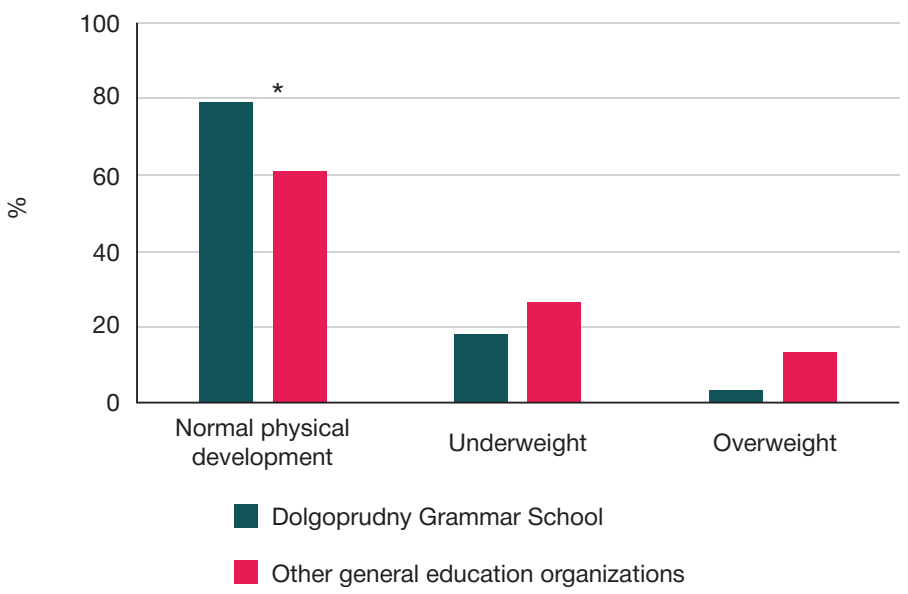

Fig. Senior schoolchildren from the Dolgoprudny Grammar School and other general education organizations of Dolgoprudny by level of their physical development $(p<0.05)$ 
Cluster analysis based on the dynamics of the studied indicators allowed dividing the schoolchildren into groups. On average, schoolchildren and students who have successfully mastered the hygiene education program spent less time using their smartphones during the day and had better physical development indicators (see Table).

Thus, their average body fat mass was $12 \mathrm{~kg}$ and that of students that did not learn the hygienic education program effectively was $14 \mathrm{~kg}$ ( $p \leq 0.001)$. The results of comparison of the groups by the excess body weight were significant $(p \leq 0.004)$. Schoolchildren that received no hygiene education or responded poorly to the effort were 2.44 times more likely (OR - 0.41; 95\% Cl: 0.23-0.73) to gain excess weight than those who mastered th program, the relative risk for the former being 2.01 (95\% Cl: 1.29-3.21).

Through the two years of the study, it allowed increasing the share of Dolgoprudny Grammar School's senior schoolchildren with normal physical development characteristics (to $79.0 \pm 1.7 \%$; $p \leq 0.01)$. The comparison was made with other general education organizations of the city that did not offer hygiene education to their pupils. In these schools, the number of senior schoolchildren whose physical development could be considered normal was low $(61.0 \pm 1.5 \%)$ (see Figure).

Only $25 \%$ of the senior schoolchild ren from Dolgoprudny Grammar School had dynamometry indicators below average, while the same share among their peers from other schools was $45 \%$ ( $p \leq 0.05)$, which may indicate they suffer from a physical activity deficit.

Questionnaires filled by the schoolchildren and students when the hygiene education program was complete revealed smaller number of complaints about eye conditions from the participants, as well as the decrease of the share of schoolchildren and students not having the ED safe use skills to $20 \%$ and $25 \%$, respectively.

In addition, as part of the hygiene curriculum practice, professors gave medical students general cultural competencies using business game elements, web quests, which motivated the said students to not only lead a healthy lifestyle but also to study the subject. Some students began to call themselves "rational nutrition bloggers", "health bloggers", "ED safe use bloggers" etc. They became more active in publishing $\mathrm{HL}$ related information to their blogs and their social media pages, which is a good $\mathrm{HL}$ promotion experience for future doctors.

\section{DISCUSSION}

The current education system is a "risk zone": the educational process intensifies, and this intensification entails mental loads, poor physical activity, lack of night sleep, work-rest balance violations [19-22]. The learning process is dynamic, highly labor intensive; there is a wide range of forms and methods of teaching used, the amount of information involved is growing, and educational technologies rely on ED, which makes children, adolescents and youth draw upon their adaptation reserves [23-29]. In such conditions, popularization of HL and ED safe use skills should be an effective preventive measure $[12,13,15]$. With the educational environment turning digital, raised awareness of the safe use of ED and the related $H L$ principles, as well as mastered skills needed to implement them, should be the basis for safe behavior of the educational process participants (teachers/professors, medical workers, schoolchildren/students) [30].

This study has shown that all categories of respondents consider internet to be the most popular source of information on health maintenance. As for the "sources" of HL-related information, two-thirds of students said such were their professors, and more than half of schoolchildren - their parents. This should be taken into account by parents of schoolchildren and teachers when they develop the general cultural competence in youth. It also necessitates raising the $\mathrm{HL}$ awareness among adults and fostering their HL skills practiced both in their professional activities and everyday life [15, 30]. In view of development of the digital educational environment, it is advisable to improve the training of teachers on the safe use of ED and $\mathrm{HL}$ principles [2, 15].

Previous studies have shown that over a third of parents (35\%) and teachers (40\%) lack ED safe use skills. Among medical students, the share of those belonging to the same "risk group" was 40\%, and among schoolchildren - 35\% [15].

The study allowed formulating the key points that need to be added to the program of hygiene education of schoolchildren and students aimed at teaching them ED safe use skills:

- keeping the correct work-rest balance, rational organization of night sleep and physical activity;

- reduction of the ED use time to 3 hours a day, with breaks every 40 minutes -1 hour;

- training eye strain prevention exercises and exercises to relieve general fatigue;

- use of apps to monitor screen time, physical activity and other parameters;

- participation in social media groups/pages maintained by medical organizations and containing correct information on health and healthy lifestyle;

- increasing motivation to participate in hygiene education programs by using innovative elements popular among young people, stimulating interest among medical students to blog in the field of health;

- involvement of the closest circle of schoolchildren and students (parents, teachers, professors) in promoting healthy lifestyles.

The data obtained allows recommending the tested program for the purposes of teaching hygiene to the younger generation, their parents and specialists the professional duties of which include giving youth the knowledge, skills and abilities to use ED safely and lead a healthy lifestyle.

\section{CONCLUSION}

The study has shown the effectiveness of giving hygiene education to schoolchildren and medical students aimed at development of the electronic devices safe use skills and relying on traditional and innovative teaching methods. To increase the effectiveness of hygiene education, it is necessary to also popularize HK among teachers and parents, whom children, adolescents and youth perceive as carriers of the relevant information. $\mathrm{HL}$ promotion should be included in the preventive discipline curricula, for example, the hygiene course read to the medical and pediatric faculty students, since in their future professional activities they will become "sources" of information about $\mathrm{HL}$ for the younger generation and the patients. It is strongly recommended to teach various categories of the population the techniques of monitoring parameters related to physical activity, sleep, screen time control etc. Mobile apps installed on personal smartphones can enable such monitoring. We suggest judging the degree of mastering the hygiene education program by the participants' level of awareness about risk factors associated with uncontrolled use of ED and their ED safe use skills. The assessment may rely post-course polling of the participants. The tested methods are not costly; they can be replicated in other regions and organizations. 
1. Pasport prioritetnogo proekta "Formirovanie zdorovogo obraza zhizni", utverzhdennogo prezidiumom Soveta pri Prezidente Rossijskoj Federacii po strategicheskomu razvitiju i prioritetnym proektam (protokol ot 26 ijulja 2017 g. №8). Dostupno po ssylke: http://government.ru/news/28745/. Russian.

2. Sokolova NV, Popov VI, Kartysheva SI, Koroleva AO. Nekotorye aspekty profilakticheskoj dejatel'nosti uchitelja, napravlennoj na uluchshenie sostojanija zdorov'ja shkol'nikov. Gigiena i sanitarija. 2014; 93 (1): 90-91. Russian.

3. Kaprin AD, Aleksandrova LM, Starinskij W. Mediko-social'nye aspekty formirovanija $v$ Rossii koncepcii zdorovogo obraza zhizni. Rossijskij medicinskij zhurnal. 2017; 25 (14): 995-9. Russian.

4. Krylov VM, Krylova AV, Ponomareva TA. Osobennosti zdorov'esberegajushhego povedenija studentov. Kazanskij social'no-gumanitarnyj vestnik. 2019; 6 (41): 28-32. Russian.

5. Fedjunin VA, Nejmyshev AV. Formirovanie gotovnosti vesti zdorovyj obraz zhizni u obuchajushhihsja. Sovremennyj uchenyj. 2020; (4): 64-68. Russian.

6. Bolshakov AM, Krutko VN, Kutepov EN, i dr. Informacionnye nagruzki kak novyj aktual'nyj razdel gigieny detej i podrostkov. Gigiena i sanitarija. 2016; (2): 172-7. Russian.

7. Kuchma VR. Gigienicheskaja bezopasnost' giperinformatizacii zhiznedejatel'nosti detej. Gigiena i sanitarija. 2017; 96 (11): 1059-63. DOI: 10.18821/0016-9900-2017-96-11-1059-1063. Russian.

8. Popov MV, Libina II, Melihova EP. Ocenka vlijanija gadzhetov na psihojemocional'noe sostojanie studentov. Molodezhny innovacionnyj vestnik. 2019; 8 (2): 676-8. Russian.

9. Milushkina OYu, Popov VI, Skoblina NA, Markelova SV, Sokolova NV. The use of electronic devices by students, parents and teachers before and after the transition to distance learning. Bulletin of Russian State Medical University. 2020; 3: 85-91. DOI: 10.24075/vrgmu.2020.037.

10. Milushkina OYu, Skoblina NA, Markelova SV, Tatarinchik AA, Melikhova E, Libina II, et al. The impact of electronic devices on the physical growth and development of the modern youth and recommendations on their safe use. Bulletin of Russian State Medical University. 2019; 4: 83-89.

11. Skoblina NA, Shpakou A, Milushkina O, Markelova SV, Kuzniatsou A, Tatarinchik AA. Eye health risks associated with the use of electronic devices and awareness of youth. Klinika Oczna / Acta Ophthalmologica Polonica. 2020; 122 (2): 60-65. DOl:10.5114/ ko.2020.96492.

12. Dorofeev SB, Babenko Al. Nacional'nye strategii formirovanija zdorovogo obraza zhizni naselenija. Zdravoohranenie Rossijskoj Federacii. 2015; 59 (6): 44-47. Russian.

13. Cybusov AP, Atmajkina OV, Utkina LI. Formirovanie i upravlenie zdorov'esohranjajushhim povedeniem rossijan - aktual'naja neotlozhnaja gosudarstvennaja zadacha. Medicinskij al'manah. 2017; 2 (47): 10-13. Russian.

14. Shalnova SA, Balanova YuA, Deev AD, Koncevaja AV, Imaeva AYe, Kapustina AV, i dr. Integral'naja ocenka priverzhennosti zdorovomu obrazu zhizni kak sposob monitoringa jeffektivnosti profilakticheskih mer. Profilakticheskaya meditsina. 2018; 21 (4): 65-72. Russian.

15. Markelova SV. The role of printed and electronic publications in development of vision disorders. Fundamental and Clinical Medicine. 2020; 8 (329): 50-57.

16. Kuchma VR, Sedova AS, Stepanova MI, Rapoport IK, Polenova MA
Sokolova SB, i dr. Osobennosti zhiznedejatel'nosti i samochuvstvija detej i podrostkov, distancionno obuchajushhihsja vo vremja jepidemii novoj koronavirusnoj infekcii COVID-19. Voprosy shkol'noj i universitetskoj mediciny i zdorov'ja. 2020; 2: 4-19. Russian.

17. Baranov AA, KuchmaVR, SuharevaLM, RapoportIK, Pavlovich KYe, i dr. Provedenie monitoringa sostojanija zdorov'ja detej i podrostkov i organizacija in ozdorovlenija. Metodicheskie rekomendacii. M.: NCZD, 2006; 47 c. Russian.

18. Pivovarov YuP, Skoblina NA, Milushkina OYu, Markelova SV, Fedotov DM, Okolnikov FB, et al. Use of internet surveys in the assessment of awareness of the basics of a healthy lifestyle. Current problems of health care and medical statistics. 2020; (2): 398-413.

19. Kuchma VR, Suhareva LM, Stepanova MI, Hramcov PI, Aleksandrova IYe, Sokolova SB. Nauchnye osnovy i tehnologii obespechenija gigienicheskoj bezopasnosti detej v «Cifrovoj shkole». Gigiena i sanitarija. 2019; 98 (12): 1385-91. Russian.

20. Polenova MA. Informacionno-obrazovatel'nye nagruzki kak faktor riska zdorov'ju shkol'nikov. Zdorov'e naselenija i sreda obitanija. 2015; 10: 20-22 Russian.

21. Hramcov PI. Fiziologo-gigienicheskie predposylki povyshenija zdorov'esberegajushhej jeffektivnosti fizicheskogo vospitanija detej v obrazovatel'nyh organizacijah. Voprosy shkol'noj i universitetskoj mediciny i zdorov'ja. 2017; 4: 15-20. Russian.

22. Lukjanec GN, Makarova LV, Paranicheva TM, Tjurina EV, Shibalova MS. Vlijanie gadzhetov na razvitie detej. Novye issledovanija. 2019; 1 (57): 25-35. Russian.

23. Kuchma VR, Tkachuk EA. Ocenka vlijanija na detej informatizaci obuchenija i vospitanija $\vee$ sovremennyh uslovijah. Rossijskij pediatricheskij zhurnal. 2015; 6: 20-24. Russian.

24. Soldatova GU, Rasskazova El. «Oborotnaja storona» cifrovoj kompetentnosti rossijskih podrostkov: illjuzija kompetentnosti i riskovannoe povedenie onlajn. Voprosy Psychologi. 2017; 3: 3-15. Russian.

25. Stepanova Ml. Gigienicheskaja bezopasnost' cifrovoj obrazovatel'noj sredy dlja detej i podrostkov. Pedagogika. 2018; 12: 38-46. Russian.

26. Laks M, Guerra CM, Miraglia JL, Medeiros EA. Distance Learning in Antimicrobial Stewardship: Innovation in Medical Education. PMID: 31174524; PMCID: PMC6555969; DOI: 10.1186/s12909019-1623-x.

27. Maria B, Oleksandr K, Valentina E, Olena Y. Distance-pedagogical technologies in olympic education for schoolchildren Journal of Physical Education and Sport. 2019; 378 (4): 2497-503. Ukraine.

28. Ushakov IB, Popov VI, Petrova TN, i dr. Izuchenie zdorov'ja studentov kak rezul'tat vzaimodejstvija mediko-biologicheskih, jekologicheskih i social'no-gigienicheskih faktorov riska. Medicina truda i promyshlennaja jekologija. 2017; (4); 33-36. Russian.

29. Kuchma VR, Rapoport IK, Sokolova SB, Aleksandrova IJe, Makarova AJu, Mustafaeva KSh, i dr. Rasprostranennost' i ocenka ispol'zovanija jelektronnyh ustrojstv $\vee$ uchebnoj i dosugovoj dejatel'nosti shkol'nikov 7-8 klassov. Sechenovskij vestnik. 2015; 3 (21): 43-50. Russian.

30. Lipanova LL, Nasybullina GM, Hachaturova NL, Goncharova AS. Podgotovka medicinskih i pedagogicheskih kadrov dlja osushhestvlenija gigienicheskogo obuchenija i vospitanija detej. Vestnik Ural'skoj medicinskoj akademicheskoj nauki. 2018; 15 (3): 503-10. Russian.

\section{Литература}

1. Паспорт приоритетного проекта «Формирование здорового образа жизни", утвержденного президиумом Совета при Президенте Российской Федерации по стратегическому развитию и приоритетным проектам (протокол от 26 июля 2017 г. №8). Доступно по ссылке: http://government.ru/ news/28745/.

2. Соколова Н. В., Попов В. И., Картышева С. И., Королева А. О. Некоторые аспекты профилактической деятельности

учителя, направленной на улучшение состояния здоровья школьников. Гигиена и санитария. 2014; 93 (1): 90-91.

3. Каприн А. Д., Александрова Л. М., Старинский В. В. Медикосоциальные аспекты формирования в России концепции здорового образа жизни. Российский медицинский журнал. 2017; 25 (14): 995-9.

4. Крылов В. М., Крылова А. В., Пономарева Т. А. Особенности здоровьесберегающего поведения студентов. Казанский 
социально-гуманитарный вестник. 2019; 6 (41): 28-32.

5. Федюнин В. А., Неймышев А. В. Формирование готовности вести здоровый образ жизни у обучающихся. Современный ученый. 2020; (4): 64-68.

6. Большаков А. М., Крутько В. Н., Кутепов Е. Н. и др. Информационные нагрузки как новый актуальный раздел гигиены детей и подростков. Гигиена и санитария. 2016; 2: $172-7$.

7. Кучма В. Р. Гигиеническая безопасность гиперинформатизации жизнедеятельности детей. Гигиена и санитария. 2017; 96 (11): 1059-63. DOI: 10.18821/0016-9900-2017-96-11-1059-1063.

8. Попов М. В., Либина И. И., Мелихова Е. П. Оценка влияния гаджетов на психоэмоциональное состояние студентов. Молодежный инновационный вестник. 2019; 8 (2): 676-8.

9. Милушкина О. Ю., Попов В. И., Скоблина Н.А., Маркелова С. В., Соколова Н. В. Использование электронных устройств участниками образовательного процесса при традиционной и дистанционной формах обучения. Вестник Российского государственного медицинского университета. 2020; 3: 85-91.

10. Милушкина О. Ю., Скоблина Н. А., Маркелова С. В., Татаринчик А. А., Мелихова Е. П., Либина И. И. и др.. Влияние электронных устройств на физическое развитие современной молодежи и рекомендации по регламенту их использования. Вестник Российского государственного медицинского университета. 2019; 4: 83-89.

11. Скоблина Н. А., Шпаков А., Милушкина О. Ю., Маркелова С. В., Кузнецова А., Татаринчик А. А. Риски для здоровья глаз, связанные с использованием электронных устройств и осведомленность молодежи. Klinika Oczna / Acta Ophthalmologica Polonica. 2020; 122 (2): 60-65. DOI: 10.5114/ ko.2020.96492.

12. Дорофеев С. Б., Бабенко А. И. Национальные стратегии формирования здорового образа жизни населения. Здравоохранение Российской Федерации. 2015; 59 (6): 44-47.

13. Цыбусов А. П., Атмайкина О. В., Уткина Л. И. Формирование и управление здоровьесохраняющим поведением россиян актуальная и неотложная государственная задача. Медицинский альманах. 2017; 2 (47): 10-13.

14. Шальнова С. А., Баланова Ю. А., Деев А. Д., Концевая А. В., Имаева А. Э., Капустина А. В. и др. Интегральная оценка приверженности здоровому образу жизни как способ мониторинга эффективности профилактических мер. Профилактическая медицина. 2018; 21 (4): 65-72.

15. Маркелова С. В. Роль родителей, учителей, медицинских работников в формировании знаний, умений и навыков безопасного использования электронных устройств старшими школьниками. Здоровье населения и среда обитания. 2020; 8 (329): 50-57.

16. Кучма В. Р., Седова А. С., Степанова М. И., Рапопорт И. К., Поленова М. А., Соколова С. Б. и др. Особенности жизнедеятельности и самочувствия детей и подростков, дистанционно обучающихся во время эпидемии новой коронавирусной инфекции COVID-19. Вопросы школьной и университетской медицины и здоровья. 2020; 2: 4-19.

17. Баранов А. А., Кучма В. Р., Сухарева Л. М., Рапопорт И. К., Павлович К. Э. и др. Проведение мониторинга состояния здоровья детей и подростков и организация их оздоровления. Методические рекомендации. М.: НЦЗД, 2006; 47 с.

18. Пивоваров Ю. П., Скоблина Н. А., Милушкина О. Ю., Маркелова С. В., Федотов Д. М., Окольников Ф. Б. и др. Использование интернет-опросов в оценке осведомленности об основах здорового образа жизни. Современные проблемы здравоохранения и медицинской статистики. 2020; 2: 398-413.

19. Кучма В. Р., Сухарева Л. М., Степанова М. И., Храмцов П. И., Александрова И. Э., Соколова С. Б. Научные основы и технологии обеспечения гигиенической безопасности детей в «Цифровой школе». Гигиена и санитария. 2019; 98 (12): 1385-91.

20. Поленова М. А. Информационно-образовательные нагрузки как фактор риска здоровью школьников. Здоровье населения и среда обитания. 2015; 10: 20-22

21. Храмцов П. И. Физиолого-гигиенические предпосылки повышения здоровьесберегающей эффективности физического воспитания детей в образовательных организациях. Вопрось школьной и университетской медицины и здоровья. 2017; (4): 15-20.

22. Лукьянец Г. Н., Макарова Л. В., Параничева Т. М., Тюрина Е. В., Шибалова М. С. Влияние гаджетов на развитие детей. Новые исследования. 2019; 1 (57): 25-35

23. Кучма В. Р., Ткачук Е. А. Оценка влияния на детей инсорматизации обучения и воспитания в современных условиях. Российский педиатрический журнал, 2015; 6: 20-24.

24. Солдатова Г. У., Рассказова Е. И. «Оборотная сторона» цисровой компетентности российских подростков: иллюзия компетентности и рискованное поведение онлайн. Вопрось психологии. 2017; 3: 3-15.

25. Степанова М. И. Гигиеническая безопасность цифровой образовательной среды для детей и подростков. Педагогика. 2018; (12): 38-46

26. Laks M, Guerra CM, Miraglia JL, Medeiros EA. Distance Learning in Antimicrobial Stewardship: Innovation in Medical Education. PMID: 31174524; PMCID: PMC6555969; DOI: 10.1186/s12909019-1623-x

27. Maria B, Oleksandr K, Valentina E, Olena Y Distance-pedagogical technologies in olympic education for schoolchildren Journal of Physical Education and Sport. Journal of Physical Education and Sport. 2019; 378 (4): 2497-503. Ukraine.

28. Ушаков И. Б., Попов В. И., Петрова Т. Н., и др. Изучение здоровья студентов как результат взаимодействия медикобиологических, экологических и социально-гигиенических факторов риска. Медицина труда и промышленная экология. 2017; 4; 33-36.

29. Кучма В. Р., Рапопорт И. К., Соколова С. Б., Александрова И. Э., Макарова А. Ю., Мустафаева К. Ш. и др. Распространенность и оценка использования электронных устройств в учебной и досуговой деятельности школьников 7-8 классов. Сеченовский вестник. 2015; 3 (21): 43-50.

30. Липанова Л. Л., Насыбуллина Г. М., Хачатурова Н. Л., Гончарова А. С. Подготовка медицинских и педагогических кадров для осуществления гигиенического обучения и воспитания детей. Вестник Уральской медицинской академической науки. 2018; 15 (3): 503-10. 